\title{
Resquícios do Conflito do Contestado (1912-1916): 0 Julgamento de Henrique Wolland, o Alemãozinho
}

Cássio Alexandre de Souza ${ }^{1}$

\begin{abstract}
RESUMO: No que diz respeito à História do Contestado, sobre o contexto ocorrido entre os territórios dos Estados do Paraná e Santa Catarina, é possível afirmar que existem questões ainda não explicadas, relacionadas com o litigioso conflito, que se perpetuam ao longo de um século sem esclarecimentos jurídicos e historiográficos. 0 seguinte artigo é resultado de uma pesquisa de caráter documental, com o intuito de elucidar, segundo o Processo Judicial, o julgamento de Henrique Wolland, vulgo Alemãozinho, e a sua trajetória no contexto deste conflito, bem como a repercussão de sua passagem pela Comarca da cidade de Rio Negro, entre os anos de 1914 a 1916.
\end{abstract}

Palavras-Chave: Henrique Wolland; Contestado, Processo Judicial, Rio Negro.

\section{Remains of the Contest of the Contestant (1912-1916): The Trial of Henry Wolland, the little German}

\begin{abstract}
Regarding the History of Contested on the context occurred between the territories of Paraná and Santa Catharina, it is clear that there are issues not yet explained, related litigious conflict perpetuated over a century without clarification historiographical. The following article is the result of a survey of documentary character, in order to elucidate, in the Judicial Process, the criminal trial of Henrique Wolland, aka little German, and its history in the context of this conflict, as well as the impact of its passage by the City of Rio Negro, between the years 1914-1916.
\end{abstract}

Keywords: Henrique Wolland; Disputed, Judicial Process, Rio Negro.

- Enviado em 24/10/2016

- Aprovado em 28/11/2016

\footnotetext{
${ }^{1}$ Graduado em História pela Universidade do Contestado (2014), Campus Mafra - Santa Catarina. Cursando a Pós-graduação em Política e Sociedade (Universidade do Contestado), $2016 . \quad$ E-mail: cassio.olsen.souza@gmail.com
} 


\section{INTRODUÇÃO: A TRAJETÓRIA CONHECIDA DE HENRIQUE WOLLAND, 0 ALEMÃOZINHO.}

Embora a cidade de Rio Negro não estivesse ligada diretamente com o conflito armado do Contestado, isto é, não estava situada nas zonas de combate entre as forças policiais dos Estados de Santa Catarina e Paraná e os militantes da causa contestada, a repercussão deste conflito proporcionou uma evidente relação com indivíduos que fizeram parte na íntegra do Contestado $^{1}$, bem como da História de Rio Negro. Por ocasião dos conflitos na região de Canoinhas, houve a participação efetiva do Coronel rio-negrense Nicolau Bley Netto, comandando cerca de 250 homens na campanha da Guarda Nacional contra as forças de Antônio Tavares, combatendo também em Papanduva e Itaiópolis, entre 1914 e 1915, como descreve Waldemiro Bley Júnior em sua breve biografia: "Na revolta do Contestado, mais uma vez ao lado do Governo, comandou uma coluna de 250 homens (os vaqueanos). Era na época, Cel. Comandante da Guarda Nacional do então Rio Negro". (JÚNIOR, 1987, p. 76). Nesse contexto, comandando homens a cavalo sob as ordens de Aleixo Gonçalves, se destacou no conflito Henrique Wolland, conhecido como Alemãozinho.

Como comandante do bando de cavalarianos, Alemãozinho deixou suas impressões na cidade de Rio Negro, quando por conta dos assaltos de seu piquete ${ }^{2}$ na região entre São Lourenço e Vila Nova, teria chegado junto de seus homens a cavalo em Rio Negro, no lado esquerdo do rio, atualmente na cidade de Mafra (Santa Catarina), onde teria supostamente saqueado estabelecimentos comerciais, e com arrogância e impertinência assassinado um cidadão local segundo Ayrton Gonçalves Celestino:

José Pauli, também conhecido por Pauli-Schmidt, lavrador de certa coragem, veio de Vila Nova, a cavalo, com uma fita no chapéu (sinal de que seria também militante dos fanáticos) conseguindo atravessar o bairro supostamente infestado de jagunços e veio até a cidade estudar a possibilidade de reunir alguns homens para enfrentá-los. Pretendia cercar o grupo pelo Passo, mas a população achava que devia-se aguardar a chegada da Polícia de Curitiba porque um pequeno grupo, de forma isolada não teria condições para a luta. Apesar disto José Pauli, Bannach e mais um ou dois homens, foram ter com Alemãozinho visando especialmente à devolução da arma roubada. Ao se aproximar de Alemãozinho, José Pauli além de não prestar lá as continências exigidas pelo facínora, sacou de um trabuco muito ordinário, mesmo a cavalo atirou sem conseguir mais do que chamuscar a camisa de Alemãozinho e a tentativa de um segundo tiro falhou. Diante do acontecido Pauli-Schmidt estava colocando-se em fuga, pois mal conseguira rodopiar o seu cavalo quando Alemãozinho o matara com um só tiro nas costas. Depois de bazofiar valentia e poderio, Alemãozinho desceu pela rua central e foi ter ao bar de Guilherme Maria do Valle (onde atualmente está sendo construído um prédio entre as firmas Saliba e Ritzmann); bebericou algumas cervejas 
com seu bando, deu voltas na cidade, todos a cavalo, empunhando a bandeira de São João Maria e dando vivas à causa Contestada. (DEQUECH apud CELESTINO, 2002, p. 242).

Para Maurício Vinhas de Queiroz, em sua obra Messianismo e Conflito Social, o Alemãozinho apareceu como fotógrafo no reduto de Pinheiros, no interior de Canoinhas. Baixo, louro, de olhos azuis, rosto quase sem barba e avermelhado, Henrique Wolland fora um severo comandante do piquete dos chamados Pares de França ${ }^{3}$, que poderiam de acordo com o necessário, trancar estradas, combaterem os policiais e resgatar (leia-se saquear) mantimentos e armamentos, principalmente. Em julho de 1914, as vilas de Papanduva e Itaiópolis foram tomadas por Henrique Wolland e seus homens, não oferecendo resistência a ação. Ainda em setembro do mesmo ano, travaram acirrados confrontos entre as forças policiais e os revoltosos que ocupavam as vilas, liderados por Aleixo Gonçalves, Antônio Tavares e Henrique Wolland. Na sequência desses acontecimentos, Alemãozinho teria se rendido as forças da Guarda Nacional, contrariando seus companheiros de revolta. Ao renderse, Henrique Wolland colaborou com informações detalhadas sobre os redutos, desde localização, líderes, táticas utilizadas e armamentos que os revoltosos possuíam. Acredita-se que também passou a trabalhar para as tropas legalistas no decorrer de dezembro de 1914 a janeiro de 1915. Entretanto, ficou famoso pela prática de impor regras e disciplinar seus comandados, como menciona Maurício Vinhas de Queiroz:

Alemãozinho baixou severas ordens à sua irmandade. Nos piquetes, ninguém devia falar alto, nem rir, nem beber. Não poderia entrar em casa alguma sem ordem do comandante. É proibido falar com qualquer senhora sem que seja preciso. Recomenda-se que uns tratem os outros com o maior respeito. Ninguém tenha pressa de voltar, nem pergunte para onde vai, nem de onde vem. A quem desrespeitasse essas ordens, seria dado na forma um conselho; em caso de reincidência, o indisciplinado sofreria surra de vara de marmelo, e, em caso extremo, seria morto. (QUEIROZ, 1981, p. 155).

No conflito do Contestado, as tropas do $28^{\circ}$ Batalhão de Infantaria, comandadas pelo General Setembrino de Carvalho, e do Batalhão da Polícia do Paraná sob o comando do Coronel Júlio César Gomes da Silva, ocuparam o reduto de Itaiópolis entre os meses de setembro a novembro de 1914, e as localidades de Moema e Iracema onde estavam postados parte dos revoltosos chefiados por Antônio Tavares. Em dezembro do mesmo ano, se apresentaram às tropas legalistas cerca de 300 revoltosos, a maioria velhos, mulheres e 
crianças, que foram levados para Rio Negro. Dentre esses provavelmente estava Henrique Wolland, que em fevereiro de 1915, foi intimado pela Promotoria Pública de Rio Negro para responder pelo assassinato do cidadão José Paulo Schmidt, ocorrido em agosto de 1914, durante o período das incursões das tropas de revoltosos nas cidades da região do Contestado. Em janeiro de 1915, Henrique Wolland teria supostamente entregado ao General Setembrino de Carvalho dois documentos destacados na Historiografia do Contestado, tratando-se da sua habilitação como comandante dos pares de cavalarianos, e de um código de posturas para disciplinar seus comandados no piquete. Com referência ao seu companheiro, e possivelmente seu imediato no comando, Paulo Pinheiro Machado destaca:

No auto de perguntas feito a Francisco Hieck, em Rio Negro, o depoente afirmou que foi convidado por Alemãozinho para lutar pela "Monarquia", pela "Religião" e pela "execução da sentença de limites". Afirmou ainda que Alemãozinho tinha uma "virgem" no acampamento. (MACHADO, 2004, p. 259-260).

A análise do contexto da participação do líder dos revoltosos Alemãozinho, ou do réu em questão, Henrique Wolland, baseada no conteúdo processual de sua ação judicial mostra detalhes até então desconhecidos pela historiografia documental do Contestado, portanto, o presente artigo pretende elucidar e relacionar a dimensão histórica e jurídico-processual, contemplando as referências quanto ao que está presente na referida historiografia, e o que foi reproduzido nos autos do Processo Crime contra Henrique Wolland.

\section{DO PROCESSO CRIME: O ASSASINATO DE JOSÉ PAULO SCHMIDT E O JULGAMENTO NO TRIBUNAL DO JÚRI DE RIO NEGRO, EM 1915.}

0 processo de acusação contra Henrique Wolland inicia-se, segundo a denúncia do crime enviada ao Juiz de Direito da Comarca de Rio Negro, qualificando-o como assassino e invasor, junto de seu bando, sendo o ofício de acusação encaminhado pelo Promotor Público (Dr. João Dias de Paiva) em 10 de fevereiro de 1915. Descreve Henrique Wolland como fotógrafo, natural da Alemanha, e residente no interior de Corupá (na época, colônia Hansa Humboldt) no Estado de Santa Catarina, semelhante ao que apresenta Maurício Vinhas de Queiroz, como descrito no documento: "A Promotoria Pública desta Comarca, no uso das 
attribuições, vem perante V. Ex. denunciar a Henrique Wolland, Photographo, natural da Allemanha e residente no Estado de S. Catharina". (PROCESSO CRIME, 1915, p. 02).

Prosseguindo, o texto menciona que, em 29 de agosto de 1914, um grupo de fanáticos ${ }^{4}$ a mando do denunciado invadiram a cidade de Rio Negro, tendo Henrique Wolland assassinado a tiros de revólver a vítima José Paulo Schmidt, que se encontrava na casa de Reinaldo Burghardt, onde fora na companhia de Valentim e Ignácio Bannach a fim de resgatar um revólver que teria supostamente sido roubado de Valentim pelo acusado, por ocasião de ter invadido a Casa de Comércio de Valentim. Quanto ao procedimento legal da acusação, vejamos o que se descreve: “Com este procedimento o denunciado praticou o crime previsto no art. 294 do Código Penal ${ }^{5}$, deixando de dar os paragraphos para fazer por ocasião do parecer da pronuncia, visto no inquérito não ter ficado bem esclarecido as circunstâncias do crime". (idem; ibidem, p. 02).

0 ofício encaminhado pela Promotoria Pública ao Juiz de Direito conclui-se com a notificação de testemunhas para depor sobre o fato presenciado, bem como a requisição da prisão preventiva do acusado. Tratava-se das testemunhas: 1 - Valentim Bannach, 2 - Ignácio Bannach, 3 - Reinaldo Burghardt, 4 - Ervim Schmidt, 5 - Emílio Goldbach e 6 - Francisco Heick.

Conforme apresenta o processo, entre os dias 30 e 31 de agosto de 1914, foi feita a autuação do cadáver de José Paulo Schmidt, segundo a portaria do dia 31 de agosto, redigida pelo Delegado de Polícia Otto Bussmann, onde descreve ter chegado ao seu conhecimento que o referido cadáver encontrava-se na casa do Sr. André Wormsbecker, e segue delegando as funções para apurar o caso:

Determino ao Sr. Luiz Carias de Oliveira a quem nomeio escrivão ad-hoc, que intime os senhores Dr. Mathias Piechnick e farmacêutico Conradino dos Santos Lima para procederem ao auto de corpo de delicto, hoje às 10 horas da manhã no lugar onde se acha o cadáver. (idem: ibidem, p. 02).

Formalmente, o Delegado de Polícia nomeado escrivão para o caso, Sr. Luiz Carias de Oliveira, prossegue descrevendo o termo de intimação do médico legista e do farmacêutico, para que os mesmos realizassem o exame de corpo de delito da vítima. Sendo assim, na manhã de 30 de agosto de 1914, o Dr. Mathias Piechnick e o farmacêutico Conradino dos Santos Lima realizaram a perícia de corpo de delito no cadáver de José Paulo Schmidt, estando 
estes na presença dos delegados Otto Bussmann e Luiz Carias de Oliveira, e dos senhores Antônio Ribeiro e João Luiz, tomados como testemunhas do exame realizado. Concluindo o exame, constataram os legistas que a morte fora causada por duas perfurações de balas de arma de fogo, situadas na altura lombar do peito e das costas, acertando um dos pulmões e parte da espinha dorsal. 0 que chama a atenção é o fato contraditório de que a portaria redigida pelo Delegado Otto Bussmann data de 31 de agosto, sendo que o termo de descrição do exame de corpo de delito, que logicamente procede após a portaria que faz a intimação dos legistas, data do dia 30 de agosto, na mesma hora referida na portaria do dia 31 de agosto de 1914.

No dia 9 de fevereiro de 1915, os autos foram enviados pelo delegado ao Alferes Benedito Tertuliano Cordeiro, para que tomasse conhecimento do caso. Em resposta aos autos que lhe foram enviados, no mesmo dia em Rio Negro, respondeu que o escrivão deveria então na mesma data, intimar o acusado Henrique Wolland a fim de prestar depoimentos. No mesmo dia, na sala de audiências da Delegacia fizeram-se presentes os senhores Benedito Tertuliano Cordeiro (Delegado de Polícia), Henrique Wolland e Luiz Carias de Oliveira, o Escrivão. Seguindo o protocolo de perguntas do inquérito, o documento descreve as respostas de Alemãozinho, sobre quem era: "Respondeu chamar-se Henrique Wolland, com vinte e dois anos de idade, solteiro, natural da Allemanha, photographo, residente no "Bananal", Estado de Santa Catharina, sabe ler e escrever". (idem; ibidem, p. 08).

Quando interrogado sobre sua passagem pelo município de Rio Negro, Henrique Wolland menciona que, a mando do retrato do monge José Maria veio a convite para o acampamento dos fanáticos em Ribeirão Raso, servindo as ordens de Joaquinzinho Gonçalves e seguindo para o interior de Papanduva sob o comando de Elias Antônio de Moraes, onde recebeu ordens terminantes para incendiar as casas existentes de Iracema a Papanduva, o que não o fez, deixando de cumprir o que lhe fora ordenado, com relação a incendiar as casas situadas nos lugares mencionados.

Relatou que quando chegou nesta cidade (em Rio Negro) primeiramente acampou com sua força (seus homens) na casa de um alemão chamado André, e que depois juntamente de seu companheiro Francisco Heick foram até a casa da família Buch, onde pediram comida e foram atendidos. Não satisfeito por ter chegado à cidade nesta ocasião, José Paulo Schmidt, dois irmãos Bannach e um terceiro indivíduo referido como polaco foram tirar satisfações, quando José Paulo Schmidt, supostamente alcoolizado, sacou de uma espingarda e disparou 
contra Henrique Wolland, sendo na sequência alvejado com dois tiros letais, causando-lhe a morte. Concluindo o inquérito de perguntas feitas ao réu, o Delegado de Polícia Benedito Tertuliano Cordeiro ordena ao escrivão para que intime para deporem sobre a ocorrência as testemunhas Valentim Bannach, Ignácio Bannach, Reinaldo Burghardt, Ervim Schmidt, Emílio Goldbach e Francisco Heick, em 9 de fevereiro de 1915.

Em síntese dos depoimentos das testemunhas, realizadas no inquérito, destacam-se, além de suas versões dadas ao fato ocorrido, o ponto de vista de cada indivíduo tomado como testemunha:

1믄 Testemunha (Valentim Bannach):

Diz que Henrique Wolland foi à casa de Ignácio Bannach, onde teria invadido a mesma e tomado para si um revólver de propriedade de Ignácio, e assim qualifica Henrique Wolland: "[...] homem perverso, autor de diversos roubos". (idem; ibidem, p. 10). Alegou que na noite do crime, foram ao encontro de Henrique Wolland na casa de Reinaldo Burghardt, para tentar resgatar o revolver que supostamente foi roubado pelo acusado.

2aㅗ Testemunha (Ignácio Bannach):

Diz que ao ser abordado por Henrique Wolland em sua casa, o mesmo lhe pediu que emprestasse um revólver, e perguntou onde poderia encontrar dinamites. Como resposta, Ignácio Bannach teria dito que isto era impossível, pois possuía somente um revólver. Prosseguindo, menciona que Henrique Wolland invadiu um quarto e tomou para si o revólver. Justificou que foram até a casa de Reinaldo Burghardt, já a noite, onde se encontrava Henrique Wolland, a fim de resgatar o revólver roubado pelo mesmo, quando houve disparos, sendo que alguns tiros atingiram fatalmente José Paulo Schmidt, e que em seguida evadiram-se rapidamente do local, visto que o acusado disparou mais cinco tiros em sua direção. Disse ainda que além do revólver, Henrique Wolland também teria roubado do interior da sua casa duas caixas de balas de revólver, depoimento este que fora contestado por Henrique Wolland, alegando não ser verdade o que se referiu sobre o suposto roubo.

3몬 Testemunha (Reinaldo Burghardt): 
Diz que ao chegar a sua casa, tomou conhecimento de que suas carroças teriam sido apreendidas pelos fanáticos. Mencionou que foi ao comandante dos fanáticos, Henrique Wolland, pedir-lhe autorização para retirar suas carroças, e que o mesmo deu-lhe então uma autorização por escrito, para que apresentasse aos seus comandados e retirasse as suas carroças. Segundo descrito no documento, em 29 de agosto de 1914: “[...] amedrontado, convidou Henrique Wolland (acusado) para seiar em sua casa". (idem; ibidem, p. 12). Ao término do jantar (como descrito no inquérito, $\underline{\text { seiar) }}$ perceberam certa movimentação fora de sua casa, e então, Henrique Wolland e Francisco Heick saíram para ver do que se tratava, sendo recebidos na varanda da casa a tiros, disparados pelos homens postados em frente à casa, o que em seguida, Henrique Wolland teria disparado contra os mesmos, acertando fatalmente dois tiros de revólver no peito de José Paulo Schmidt, causando-lhe a morte.

4⿳亠口冋 Testemunha (Ervim Schmidt):

Menciona que na casa de Reinaldo Burghardt, Henrique Wolland e Francisco Heick despediram-se, e, ao saírem, depararam-se entre outros com José Paulo Schmidt que atirou sem acerto contra Wolland, e na sequência, que o mesmo teria alvejado José Paulo Schmidt com seis tiros de revólver, acertando-lhe fatalmente dois tiros no peito.

5aㅗ Testemunha (Emílio Goldbach):

Diz que na noite do dia 29 de agosto de 1914 chegou à casa de Reinaldo Burghardt e deparou-se com Henrique Wolland e Francisco Heick, que estavam saindo, e que ouviu o disparo de tiros contra os mesmos, cujas balas teriam atingido a porta da varanda da casa, pela qual saíram. Diz ainda que em seguida, ouviu vários tiros, e evadiu-se do local, tomando conhecimento da morte de José Paulo Schmidt somente no dia seguinte.

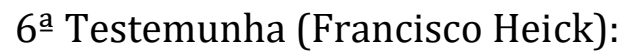

Diz Francisco Heick que, estando na companhia de Henrique Wolland, após saírem da casa de Reinaldo Burghardt, ouviu tiros contra eles, e logo em seguida: "[...] diversos tiros seguidos foram dados por seu companheiro". (idem; ibidem, p. 14).

Para concluir o inquérito das testemunhas do crime, o Relatório Oficial do Delegado de Polícia, Benedito Tertuliano Cordeiro, concluiu que no dia 29 de agosto de 1914, às sete horas da noite aproximadamente, um grupo de fanáticos: “[...] a mando de Henrique Wolland 
invadiram esta cidade, tendo este covardemente assassinado a tiros de revólver, conforme auto de corpo de delito, a José Paulo Schmidt, em casa de Reinaldo Burghardt". (idem; ibidem, p. 15). Na ocasião, José Paulo Schmidt (em companhia de Valentim e Ignácio Bannach), dirigiuse a casa de Reinaldo a fim de resgatar o revólver pertencente a Valentim, que em momentos antes havia sido roubado por Henrique Wolland, quando o mesmo teria invadido a casa dos irmãos Bannach. Ainda segundo o relatório, Henrique Wolland confirmou grande parte das acusações feitas contra ele, bem como afirmou ser o único responsável pelo assassinato de José Paulo Schmidt. Concluindo o Relatório, o Delegado de Polícia encaminha-o ao Juiz de Direito da Comarca, solicitando conforme os termos legais, a prisão preventiva do acusado Henrique Wolland, ainda no dia 9 de fevereiro de 1915: "[...] peço permissão à Autoridade competente para ponderar a conveniência da prisão preventiva do mesmo, que pretende escapar a ação da Justiça". (idem; ibidem, p. 15).

Em seguida, após a remessa dos autos encaminhada para o Promotor Público e para o Juiz, no dia 10 de fevereiro de 1915, o Dr. José Cesar de Almeida (Juiz de Direito da Comarca de Rio Negro), expediu o mandado judicial de prisão preventiva do acusado Henrique Wolland, como se descreve:

[...] que prenda nesta cidade o denunciado Henrique Wolland e recolha-o a cadeia pública desta cidade, visto haver o Doutor Promotor Público offerecido denúncia contra ele pelo crime previsto no Art. 294 do Código Penal e, em vista dos veementes indícios de culpabilidade do mesmo, haver requerido a sua prisão preventiva. 0 QUE CUMPRA-SE. (idem; ibidem, p. 18).

No dia 11 de fevereiro de 1915, em uma praça não identificada de Rio Negro, o Oficial de Justiça, Sr. Juvêncio de Oliveira, abordou o acusado e apresentou-lhe o Mandado de Prisão: "Intimei a Henrique Wolland, depois de me ter dado a conhecer e de lhe apresentar o mesmo mandado, para que me acompanhasse incontinenti ${ }^{6}$, e como obedeceu, conduzi a cadeia pública, onde ficou recolhido preso". (idem; ibidem, p. 18). Prosseguindo, o Juiz de Direito solicitou a intimação das testemunhas supracitadas, no dia 13 de fevereiro às 12 horas, para os depoimentos do processo cujo réu era Henrique Wolland, na sala de audiências do Prédio da Câmara Municipal de Rio Negro.

Na audiência, frente ao Dr. João Dias de Paiva e o Dr. José Cesar de Almeida, novamente as testemunhas prestaram depoimentos. Henrique Wolland, que estava preso há dois dias, foi 
intimado a comparecer e também depor em sua defesa, segundo a portaria do dia 13 de fevereiro, redigida pelo escrivão Dagoberto José Corrêa:

MANDO ao carcereiro da Cadeia Pública desta Cidade, sendo-lhe esta apresentada, indo por mim assignada, faça comparecer hoje às doze horas, devidamente escoltado, na sala das audiências deste juízo, o réo Henrique Wolland, a fim de ser o mesmo qualificado e assistir a inquirição de testemunhas. O QUE CUMPRA-SE. (idem; ibidem, p. 26).

A respeito dos depoimentos do Inquérito Policial, Valentim Bannach inicia a sessão dizendo que o roubo do revólver e de duas caixas de balas ocorreu em sua casa, às 16 horas, em uma sala nos fundos da casa de negócios, e que após o ocorrido, Henrique Wolland e seus homens teriam seguido para a Vila Nova, uma vila de alemães que se localizava a cerca de 5 quilômetros do local do crime. Ignácio Bannach disse que no dia 29 de agosto de 1914, o acusado teria ido a sua casa de negócios, aproximadamente às 16 horas, e que o mesmo estava interessado em comprar dinamites. Tendo Henrique Wolland entrado em um quarto anexo a mesma, teria então achado o revólver pendurado na parede por um prego, o qual tomou para si sem por ele pagar nada, levando consigo também duas caixas de balas furtadas do interior do estabelecimento. Confirma que quando foram até a casa de Reinaldo Burghardt, o acusado teria disparado contra eles diversos tiros, dos quais atingiram José Paulo Schmidt que veio a falecer. As demais testemunhas apenas replicaram o que já haviam dito no depoimento anterior.

Após a audiência, entre os dias 18 e 27 de fevereiro, a Promotoria Pública apontou uma nova testemunha para o caso, Thomaz Hack (ou Koch), que por motivo não esclarecido nos autos, substituiu a testemunha Francisco Heick, que estava junto de Henrique Wolland na ocasião do assassinato. Segundo a Portaria do dia primeiro de março:

MANDO a qualquer Oficial de Justiça deste Juízo, a quem for este apresentado, indo por mim assignado, que intime a Thomaz Hack, rezidente no rocio desta Cidade, para comparecer perante este Juízo no dia 5 do mez corrente, às doze horas, na sala das audiências, na Casa da Câmara Municipal, a fim de, como testemunha, depor o que souber e perguntado lhe for acerca do Processo Crime em que é autora a Justiça Pública e réo Henrique Wolland, intimando-se igualmente a este para se ver processar, sob pena, a testemunha de desobediência e ao réo de revelia. O QUE CUMPRA-SE. (idem; ibidem, p. 33). 
Na sequência da intimação para depor sobre o caso, Thomaz Hack então compareceu na sala de audiências da Câmara Municipal, em 5 de março de 1915, para que fosse realizado o inquérito de seu testemunho frente ao réu Henrique Wolland, o Juiz de Direito e o Promotor Público. Em seu depoimento, Tomaz Hack repetiu a descrição dos fatos ocorridos no dia 29 de agosto de 1914, sendo similares aos demais depoimentos. Os autos do Processo Criminal foram protocolados no Cartório de Dagoberto José Corrêa, escrivão de notas, em 10 de março de 1915. No dia 12 de março, Henrique Wolland recebeu nova intimação judicial para ser interrogado:

MANDO ao carcereiro da Cadeia Pública desta Cidade que sendo-lhe esta apresentada, indo por mim assignada, faça comparecer hoje as doze horas, devidamente escoltado, na sala de audiências deste Juízo, o réo Henrique Wolland, afim de ser o mesmo interrogado. 0 QUE CUMPRA-SE. (idem; ibidem, p. 39).

Sendo concluídos os depoimentos das testemunhas, no dia seguinte foi apresentada a defesa escrita do réu: "Henrique Wolland, preso na Cadeia Pública desta cidade e denunciado pelo crime prescrito no Art. 294 do Código Penal, vem apresentar as razões que de direito e de facto caracterizam sua defesa". (idem; ibidem, p. 41). No texto de defesa das acusações dispostas contra ele, o advogado de Henrique Wolland apresenta quatro argumentos para comprovar sua inocência quanto ao crime:

1ํ - Diz que se achava, em 29 de agosto de 1914, na casa de Reinaldo Burghardt, aproximadamente às 9 horas da noite quando alguém bateu na porta da casa, e quando Henrique Wolland fora abrir para ver de quem se tratava deparou-se com alguns homens armados (José Paulo Schmidt, Valentim e Ignácio Bannach entre outros). Menciona que José Paulo Schmidt, com um revólver na mão e em estado exaltadíssimo de embriaguez, lhe dirigiu palavras ameaçadoras e provocantes, e que disparou contra ele dois tiros, sendo que um perfurou parcialmente seu paletó. Justifica que estando a sua vida em perigo não pode absterse; então, tomou o revólver de sua cintura e disparou tiros na direção de Schmidt: "não com a intenção de matá-lo, mas para amedrontá-lo a fim de retirar-se”. (idem; ibidem, p. 41).

$2^{\text {o }}$ - De parte de Schmidt e de seus companheiros havia a intenção de matá-lo, se por acerto os disparos do mesmo o tivessem atingido, acertando assim o alvo desejado. 
3ํ - Que o fato de José Paulo Schmidt e seus companheiros irem diretamente armados ao encontro de Henrique Wolland, em altas horas da noite, manifestaram de modo insofismável a intenção que tinham de matá-lo.

4o - Que o fato de Henrique Wolland disparar tiros de revólver para o lado de José Paulo Schmidt foi unicamente para defender sua vida, pois se achava em perigo, e que em face do que dispõe o Art. 32 do Código Penal, § 2ำ , o acusado não é criminoso.

A defesa escrita de Henrique Wolland, postulada em juízo pelo advogado do réu (o Dr. João Ribeiro de Macedo Filho), em argumentos conclui-se apresentando as testemunhas de defesa, que foram Reinhold Hendler, residente em Lucena, João Dammeschutz, residente em Canoinhas, no Contestado, e Thomaz Koch, residente em Jaraguá (Santa Catarina). A conclusão do Promotor Público, com relação às alegações de defesa do réu, entendeu que a justificativa baseada no Art. $32 \S 2^{\text {}}$ do Código Penal não isentava a culpa do réu, visto que era público e notório que o mesmo apresentou atitude hostil e provocadora, e que, ao que lhe constava dos autos das testemunhas, o réu teria procurado por dinamites com intenções malévolas, como descreve. Qualifica a atitude do réu de assassinar José Paulo Schmidt com a expressão: “[...] movido pela sede de sangue foi que assassinou a infeliz vítima". (idem; ibidem, p. 43).

Por esse motivo, manteve convicta a sua posição quanto à acusação, enquadrando o réu nas penalidades do Art. $294 \S 2^{\circ}$ do Código Penal, em 17 de março de 1915. Em concordância com a acusação da Promotoria, o Juiz de Direito julgou procedente a denúncia, considerando também as testemunhas de acusação e o inquérito policial, referindo-se a sanção do Art. $294 \S$ $2^{\text {o }}$ do Código Penal, e concluiu seu parecer ordenando ao escrivão dos autos do processo que publicasse o nome do réu no rol dos culpados, bem como na Cadeia Pública onde estava preso, em data de 27 de março de 1915.

Em 6 de abril, o Promotor Público redigiu o Libelo ${ }^{8}$ de Crime Acusatório contra o réu, oficializando a acusação da Promotoria, contemplando a versão dos fatos em que Henrique Wolland teria roubado um revólver da casa de Valentim Bannach, e que pelas 19 horas havia sido abordado por Valentim, Ignácio e José Paulo Schmidt, que foram até a residência onde o mesmo se encontrava para resgatarem o revólver, ação cujo desfecho fora o assassinato de José Paulo Schmidt, agravando assim a situação do réu. Pediu, com base nas evidências criminais, a condenação do réu nas penalidades do Art. 294 § 2º do Código Penal, e intimou para a sessão do Júri as testemunhas já citadas. 
Destaca-se que, o Coronel Felipe Kirchner ${ }^{9}$, enquanto Juiz de Direito interino do Dr. José Cesar de Almeida, ordenou por escrito que fossem entregues o Libelo Acusatório e o rol das testemunhas para maiores esclarecimentos do réu, em 15 de abril de 1915:

Receba o libello; entregue-se cópia dele e do rol das testemunhas ao réo preso; notifique-se lhe ao mesmo para apresentar sua contrariedade, bem como para responder na próxima sessão do jury que se haverá de convocar e logo que constar o dia da reunião do dito jury, e expeçam-se os necessários mandados, afim de que na forma da lei e como se requeira no final do libello, sejam notificadas as testemunhas para comparecerem. (idem; ibidem, p. 48).

$\mathrm{Na}$ continuidade do procedimento judicial ordenado pelo Juiz interino da Comarca, o escrivão Dagoberto José Corrêa certificou que na mesma data entregou ao réu cópia do libelo acusatório e do rol das testemunhas, como assim descreve: “[...] intimei, na cadeia pública desta cidade, o réo Henrique Wolland, por todo o conteúdo do mesmo despacho, do que ficou bem sciente; igualmente, certifico que entreguei ao mesmo réo cópia do libello e do rol das testemunhas". (idem; ibidem, p. 48). Em seguida, Henrique Wolland certifica conforme sua assinatura, a seguinte afirmação: "recebi a cópia do libello crime accusatório e do ról das testemunhas, pelo crime do qual estou sendo accusado". (idem; ibidem, p. 49). No dia 15 de maio, o Dr. José César de Almeida divulgou oficialmente o edital de membros do Júri que estariam convocados para a sessão ordinária do julgamento do réu Henrique Wolland, como se descreve:

O Doutor José Cesar de Almeida faz saber que tendo designado o dia quinze do mês de junho próximo vindouro, pelas onze horas da manhã, para abrir a segunda sessão ordinária do Jury deste Termo, e havendo procedido ao sorteio dos quarenta e oito jurados que têm de servir na mesma sessão, foram sorteados os seguintes cidadãos: 1 - Adolpho Bley, 2 - Roldão Amalio Ribas, 3 - Theodoro Bostelmann, 4 - Theodoro Ruthes Sobrinho, 5 - Thobias Athos de Cassias, 6 - Paulino Amálio Ribas, 7 - Emílio Metzger, 8 - Ernesto Gustavo Uhlmann, 9 - Carlos Zornig, 10 - Augusto Henrique Müller, 11 - José Maria Cardoso Júnior, 12 - Emílio Von Linsingen, 13 - Otto Bussmann, 14 - Heleodoro Xavier de Almeida, 15 - Otto Buch, 16 - Salvador Sabóia, 17 - Leopoldo Xavier de Almeida, 18 - Francisco Fischer, 19 - Brazílio Celestino de Oliveira, 20 - Guilherme Kühl, 21 - José Valério, 22 - Paulo Stoterau, 23 - Henrique Stahlke, 24 - Conradino dos Santos Lima, 25 - Carlos Schneider, 26 - Nicolau Bley Netto, 27 - José Guilherme Valério, 28 - Júlio Timm, 29 - José Pedro Grein, 30 - João Henning, 31 - Doutor Joaquim Ferreira do Amaral e Silva, 32 - Guilherme Camillo Ruthes, 33 - Wilibaldo Schwartz, 34 - João David Ferreira, 35 - Jovino Bussmann, 36 Ricardo Schneider, 37 - José Henrique Dias, 38 - José Bley, 39 - Alfredo Greippel, 40 Veríssimo Francisco Elias, 41 - Bruno Uhlmann, 42 - Christiano Buch, 43 - Benjamin Grein, 44 - Octávio Ladislau do Nascimento, 45 - Guilherme Danemann, 46 Frederico Zornig, 47 - Frederico Stoterau, 48 - Nicolau José Ruthes. (idem; ibidem, p. 50). 
Além dos jurados citados, também foram notificadas as testemunhas do caso, para que comparecessem a sessão ordinária do julgamento do réu. Em reunião do Júri na sessão do dia 15 de junho de 1915 (na sala das sessões do Paço Municipal) presentes o Juiz de Direito da Comarca, o Presidente do Tribunal do Júri e o Promotor Público interino, o cidadão Saturnino Olintho da Silva ${ }^{10}$, juntamente com os quarenta jurados presentes, o escrivão do Júri e as partes, lavrou-se então o termo de abertura da sessão, começando-se os trabalhos ao toque da campainha dado pelo Oficial Porteiro, às onze horas da manhã de portas abertas, sendo feita a conferência das cédulas nominais de cada jurado, bem como a notificação em Ata da ausência de oito jurados, que não responderam a chamada.

Na certidão de chamada, o Oficial de Justiça José Nunes Cavalheiro declarou que aos pregões da sala das sessões do Júri responderam o réu Henrique Wolland, acompanhado de seu advogado, o Dr. João Ribeiro de Macedo Filho, e as testemunhas Reinaldo Burghardt, Valentim e Ignácio Bannach, Ervim Schmidt, Emílio Goldbach e Thomaz Koch, e ausentes às testemunhas Reinhold Hendler e João Dammeschutz. Procedendo com a sessão de julgamento do réu, os jurados tomaram seus acentos, a Promotoria descartou seus jurados e a defesa do réu também, inclusive o farmacêutico Conradino dos Santos Lima, impedido de atuar por conta de ter sido legista do exame de corpo de delito do cadáver de José Paulo Schmidt. Sendo sorteados então os doze Juízes de Fato ${ }^{11}$, juntamente com o Juiz de Direito da Comarca, a composição do corpo de jurados do Júri estava formada.

Conforme consta na ordem das assinaturas, os Juízes leigos foram os seguintes: 1 Guilherme Danemann; 2 - Roldão Amálio Ribas; 3 - Frederico Stoterau; 4 - Veríssimo Francisco Elias; 5 - Brazílio Celestino de Oliveira; 6 - Jovino Bussmann; 7 - Carlos Schneider; 8 - Henrique Stahlke; 9 - José Bley; 10 - Francisco Fischer; 11 - Alfredo Greippel; 12 - Júlio Timm, e após a respectiva nomeação dos jurados, fora lavrado o Termo de Compromisso do Júri de Sentença, nas seguintes palavras:

[...] o primeiro jurado sorteado, como presidente interino do Jury de sentença, pronunciou em voz alta a seguinte fórmula: "Prometto pronunciar-me bem e sinceramente na presente causa, haver-me com verdade e justiça, tendo diante dos olhos a Lei, e proferir o meu voto segundo a minha consciência." E depois, sucessivamente os demais juízes de facto: "assim prometto". (idem; ibidem, p. 57). 
Prosseguiu o julgamento com o interrogatório feito ao réu Henrique Wolland, e o mesmo respondeu que assim chamava-se, aos 22 anos de idade, natural da Alemanha e residente em Rio Negro, a cerca de sete meses, dizendo também que era retratista (fotógrafo), e que sabia ler e escrever. Para as demais acusações do Promotor, bem como para a defesa do Advogado, foram novamente arroladas duas testemunhas, uma da defesa e outra da acusação do réu. Em defesa, o carteiro Thomaz Koch (ou Hack), de 21 anos, natural e residente em Jaraguá do Sul, Santa Catarina, disse que na ocasião, Henrique Wolland estava saindo da referida casa ao ser abordado por alguns homens a cavalo, e que os mesmos lhe intimidaram e dispararam tiros contra ele, o que revidou em legítima defesa, causando assim a morte de José Paulo Schmidt. Na acusação, foi tomado como testemunha do Promotor o também carteiro Reinaldo Burghardt, natural da Alemanha e residente em Rio Negro, que assimilou esclarecimentos aos de Thomaz Koch, sem mais nada a declarar. Destaca-se o procedimento jurídico tomado pelo Júri, após o depoimento das testemunhas citadas, na sala das sessões aberta:

Lidos os quezitos e entregues ao Prezidente interino do Jury de Sentença, com o processo, os doze Juízes de facto que formavam o dito Jury se retiraram para a sala secreta das deliberações, em cuja porta se collocaram os dois officiaes de Justiça (Juvêncio de Oliveira e José Nunes Cavalheiro), que por ordem do Juiz de Direito os haviam acompanhado e alli se postaram para impedir qualquer communicação. (idem; ibidem, p. 61).

Dadas as deliberações entre os jurados e o Juiz de Direito, as respostas apresentadas aos quesitos interrogados foram majoritariamente em favor do réu Henrique Wolland, ao constatarem que não houve intenção do réu de acertar a vítima com o intuito de matá-la, pois, o réu praticou o crime em defesa de sua própria vida, tendo a impossibilidade de prevenir a ação, de abster-se da mesma e de invocar e receber o socorro de autoridade pública, pois não provocou a agressão, não praticando o crime por motivo reprovado, frívolo. No resultado da votação do júri, destacam-se os seguintes quesitos:

[...] o réu não praticou o crime com superioridade em armas, de modo que o ofendido não pudesse defender-se com probabilidade de repelir a ofensa. [...] existem circunstancias atenuantes ${ }^{12}$ a favor do réu, que são as do Art. 42,§ 3ำ, o e $6^{\circ}$ do Código Penal ${ }^{13}$. Salla Secreta da Secção do Jury, aos 15 dias do mez de junho de 1915. (idem; ibidem, p. 64). 
Ao concluir-se a leitura dos votos que absolveram o réu, o parecer do Dr. José César de Almeida julgou expressamente procedente a absolvição do mesmo:

Em conformidade da decisão do Tribunal do Jury, respondendo por unanimidade de votos que o réo Henrique Wolland commeteu o crime qualificado no Art. 294, § 2ㅇo Código Penal, mas sim em defesa de sua própria pessoa, o absolvo, portanto da accusação que lhe foi intentada e mando que, findo o prazo legal, se passe em seu favor alvará de soltura se por al não achar preso, e lhe dê baixa na culpa. (idem; ibidem, p. 65).

Sendo absolvido da acusação da Promotoria Pública pelo Tribunal do Júri, Henrique Wolland nem sequer pôde gozar do Alvará de Soltura que lhe concederia a liberdade, deferido pelo Juiz de Direito, pois, logo na sequência da decisão do Júri e da Sentença do Dr. José César de Almeida, o Promotor interino recorreu ao Superior Tribunal do Estado do Paraná, interpondo o recurso contra a sentença que absolveu o réu em questão, embargando o Alvará de Soltura.

\section{CONCLUSÃO: DA APELAÇÃo DA PROMOTORIA PÚBLICA DE RIO NEGRO AO SUPERIOR TRIBUNAL DE JUSTIÇA DO PARANÁ A ABSOLVIÇÃO DE HENRIQUE WOLLAND, EM 1916.}

Em 16 de junho de 1915, o Promotor interino (Saturnino Olintho da Silva) encaminhou ao Dr. José César de Almeida um ofício comunicando que em nome da Promotoria Pública de Rio Negro recorreria da decisão interpondo o recurso de apelação para o Superior Tribunal de Justiça do Paraná, da decisão do Júri por oito votos em favor da absolvição do réu Henrique Wolland, lavrando-se então o termo de apelação. Conforme a petição do recorrente da decisão do Tribunal do Júri, foram encaminhados os autos do Processo Crime para o Superior Tribunal do Estado do Paraná, em Curitiba. Destaca-se a justificativa redigida pelo Promotor interino em razão da interposição do recurso:

Verificando-se dos autos que o conselho de sentença que absolveu Henrique Wolland, proferiu a sua decisão em completo desacordo com as provas colhidas no processo. Porquanto de tudo se conclui com muita evidência que a agressão partio do próprio réu; não só por ter ele penetrado violentamente em uma casa de negócios e de ahi subtrahido um revólver e duas caixas de balas, como também no momento de cometer o crime, foi elle quem descarregou o seu revólver contra um grupo que havia ido ali com o intuito de resgatar o revólver, como se vê pela maioria dos depoimentos das testemunhas que melhor presenciaram o facto criminoso. Donde se conclui que a agressão partio do réu pelo simples motivo de ter sido exigido dele objetos que 
momentos antes havia furtado. Como se vê o réu Henrique Wolland, não tinha absolutamente direito algum de invadir uma casa comercial e de ahi apossar-se de um revólver que se achava em um compartimento interno da mesma casa; e se assim o fez está exuberantemente provado, cometeu uma inaudita violência, começando desde ahi a agressão, que mais se acentuou no momento do crime. Ao passo que ao prejudicado pelo furto da arma, cabia o direito de disfarçar-se. Mas Henrique Wolland tendo invadido esta cidade, a frente de um grupo de fanáticos, tornou-se por isso temido, e assim era justo e natural que Valentim Bannach tivesse convidado outras pessoas para auxiliá-lo a resgatar a arma roubada pelo réu. Formou-se então um grupo do qual faziam parte a vítima, que foi ao encontro do réu no lugar para onde este se dirigio após ter se apoderado da arma. Ali chegando Valentim Bannach, exigio do réu a entrega de sua arma, pelo que exercia nesse momento um direito sagrado, qual o de procurar rehaver um objecto que era seu, e que momentos antes havia sido retirado violentamente de sua casa pelo réu. Mas o réu, já criminosamente investido do cargo de comandante de um piquete de fanáticos, com o qual ameaçava fazer a invasão desta cidade, ao defrontar com as pessoas que lhe exigiam a entrega do revólver roubado, julgou-se ofendido na sua hierarchia de chefe de bandoleiros, e por isso, em vez de submeter-se a exigência legal, entregando a arma furtada, facto esse que era de sua restrita obrigação, puchou a sua arma e detonou-a por diversas vezes, ferindo por essa forma, com um tiro a vítima Paulo Schmidt que veio a fallecer em consequência do tiro que lhe desfechou o réu. Do exposto conclui-se evidentemente que não é admissível na espécie a justificativa do Art. $32 \S 2^{\mathrm{o}}$ do Código Penal, invocado em favor do réu. Porque além da agressão ter partido do próprio réu, é absolutamente inadmissível a concorrência em seu favor, dos requisitos do Art. 34 do mesmo código. Tanto porque ele podia de um modo absoluto e seguro, obstar a ação, valendo-se para isso do interior da casa, onde se achava, no qual ficaria perfeitamente isento de qual agressão que receasse sofrer, por parte do grupo que ali fora exigir o revólver, porque a casa é domicílio inviolável, onde jamais alguém poderia penetrar; como também o réu não teve impossibilidade de invocar e receber socorro da autoridade pública, visto o facto ter se dado ás portas de uma cidade regularmente policiada, onde as autoridades se achavam e das quais o réu poderia invocar e receber socorro, evitando assim com a máxima facilidade a perpetração de um crime. Assim, a Promotoria Pública do Rio Negro, procurando desafrontar a sociedade ferida profundamente com o hediondo crime praticado pelo réu, vem apellar para o Egrégio Superior Tribunal de Justiça, que em sua alta sabedoria resolverá como for de rigorosa JUSTIÇA. (idem; ibidem, p. 69-70).

Após interpor o recurso, em julho do mesmo ano, Saturnino Olintho da Silva faleceu em Rio Negro, aos 72 anos. Entre os meses de julho a setembro de 1915, o Advogado do réu, Dr. João Ribeiro de Macedo Filho, apresentou a defesa escrita junto aos autos da Promotoria para remessa, para o despacho das mesmas ao Superior Tribunal de Justiça do Estado, encaminhadas pelo Juiz de Direito da Comarca em 6 de setembro de 1915, sendo recebidas na Secretaria do Superior Tribunal em 9 de setembro pelo secretário José Corrêa de Freitas, que apresentou os autos ao Presidente do Tribunal (o Desembargador Dr. Oliveira Portes) em 20 de setembro de 1915.

Entre os meses de setembro á dezembro, a defesa do Processo de Henrique Wolland e o recurso de apelação da Promotoria Pública de Rio Negro foram analisados pelos Desembargadores do Tribunal, e desfechou-se na conclusão em favor da acusação do réu, 
segundo o parecer do então Procurador-Geral de Justiça do Estado do Paraná, o Dr. Líbero Badaró Nogueira Braga, onde descreve: “[...] a justificativa de legítima defesa própria excluí toda e qualquer criminalidade ou penalidade do agente, e o reconhecimento das circunstâncias atenuantes, embora irregularmente, só servindo para minorar a pena, é evidente que o Júri contraditou-se". (idem; ibidem, p. 76).

Internamente, no Superior Tribunal de Justiça do Estado do Paraná, trataram da análise do recurso (além do Procurador-Geral de Justiça) os desembargadores Dr. Olavo de Mattos, Dr. Amaral Valente, Dr. Santa Ritta e Dr. Octávio Ferreira do Amaral e Silva, sendo o Dr. Oliveira Portes relator da análise do recurso. Após o período da decisão jurisprudencial, o Acórdão № 2.262 de 17 de dezembro de 1915 rezava:

[...] depois de vistos, relatados e discutidos estes autos de apelação de crime de Rio Negro, em que é appellante a Justiça Pública, e appellado o réu Henrique Wolland, dou provimento ao recurso para anullando o plenário, mandar submeter o réu appellado a novo julgamento, e cito a contradição das respostas dos diversos quesitos, como está bem demonstrada no parecer do Dr. Procurador-Geral. (idem; ibidem, p. 77).

Após a decisão do Tribunal de Justiça, em 22 de dezembro, o Secretário remessou para a Comarca de Rio Negro, destinados ao Dr. José César de Almeida, os autos do Acórdão do recurso citado, sendo recebidos pelo Juiz em 3 de janeiro de 1916, e expedida a liminar de cumpra-se o Acórdão em 13 de janeiro, ordenando também que fosse feito novo Libelo de acusação da Promotoria Pública para iniciar novo julgamento do réu.

Em 15 de janeiro, o Promotor interino que assumiu o caso, o Sr. Jovino Lima, encaminhou o Libelo de crime acusatório para o Juiz de Direito, apresentando as razões da acusação, dentre as quais, constava a de crime cometido por motivo frívolo, superioridade de armas de parte do réu, e, que a vítima José Paulo Schmidt não teve condições de defender-se da ação criminosa do réu, contrariando completa e intencionalmente a decisão do Júri. As testemunhas arroladas foram: Valentim Bannach, Ignácio Bannach, Reinaldo Burghardt, Ervim Schmidt, Emílio Goldbach e Thomaz Koch. Ficou claro que a Promotoria Pública investiria, segundo o Libelo, em argumentos que já haviam sido contrariados segundo a decisão anterior do Júri, embora a mesma tecnicamente estivesse em contradição. Em 5 de fevereiro de 1916, foi expedido o edital da lista dos membros do Júri, ficando assim convocado: 
1 - Guilherme Lüders; 2 - Francisco Fischer; 3 - Felippe Pallazzo; 4 - Leopoldo Petters; 5 - Alberto Stange; 6 - Carlos Schneider; 7 - Leonardo Arbigaus; 8 - José Pickssius Sobrinho; 9 - Evaristo Martins; 10 - Alypio Barbosa de Almeida; 11 Henrique Martin Haas; 12 - Alvaro Montano de Carvalho Cesar; 13 - Dr. Joaquim Ferreira do Amaral e Silva; 14 - Pedro Adélio Mendes de Almeida; 15 - Emílio Von Linsingen; 16 - Ervino Patsch; 17 - Luiz Brandt; 18 - Roldão Amalio Ribas; 19 - João Ruthes Sobrinho; 20 - Ernesto Buch; 21 - Gaspar Torres Pereira; 22 - Reinaldo Tyreck; 23 - José Schultz; 24 - João Hirt Filho; 25 - João Martin Haas; 26 - Emílio Metzger; 27 - Ernesto Sabóia; 28 - Ricardo Schneider; 29 - Conradino dos Santos Lima; 30 - Carlos Schmidt; 31 - Paulo Von Linsingen; 32 - Candido dos Santos Lima; 33 - Guilherme Camilo Ruthes; 34 - Lauro Grein; 35 - Christianino Schultz; 36 Leopoldo Xavier de Almeida; 37 - Theodoro Bostelmann; 38 - Ernesto Bley; 39 Guilherme Kühl; 40 - Achilles de Paula Linhares; 41 - Gumercindo Rodrigues da Cruz; 42 - Paulo Buch; 43 - Nacle Gebran; 44 - Constantino Rauen; 45 - Affonso de Sá Gama; 46 - Henrique Stahlke Filho; 47 - Jovino Lima; 48 - José Pedro Grein. (idem, 1916, p. 83).

Os jurados foram então intimados, com exceção de Gaspar Torres Pereira, por não ter sido encontrado pelo Oficial de Justiça Juvêncio de Oliveira, bem como as testemunhas, com exceção de Ervim Schmidt, por não estar na cidade naquela semana, sendo intimado somente em 21 de fevereiro na Estação da Estrada de Ferro de Rio Negro-Lapa logo no que chegou de viagem, conforme descreve o documento citado. Reunidos na Sala das Sessões do Júri, no prédio do Paço da Câmara Municipal, em 10 de março de 1916, às onze horas, iniciou-se o segundo julgamento do réu Henrique Wolland, na presença dos doutores José Cesar de Almeida (Juiz de Direito) e Antônio Franklin de Araújo Silva (Promotor Público), jurados, testemunhas e demais circunstantes, no que foram dados os quesitos em questão para a votação do Júri.

No decorrer dos procedimentos judiciais, apresentou-se como Advogado do réu o Dr. Antônio Cândido de Salles, substituindo o Dr. João Ribeiro de Macedo Filho, devido a sua desistência da defesa do réu. Para comporem a mesa da Presidência do Júri, foram sorteados os jurados: Henrique Stahlke Filho, Theodoro Bostelmann, Ernesto Sabóia, Luiz Brandt, Reinaldo Tyreck, Paulo Buch, Gumercindo Rodrigues da Cruz, Evaristo Martins, Carlos Schmidt, José Pedro Grein, Alberto Stange e João Hirt Filho. Encerrados os debates acerca dos quesitos apresentados pela defesa e acusação do réu, concluiu-se que estava suficientemente esclarecido, pronto o Júri para a votação e demais deliberações na sala secreta.

Constataram, segundo a votação dos quesitos, que novamente houve a concordância de que o crime foi cometido causando a fatalidade, mas que só ocorreu em legítima defesa do réu; que de sua parte, não houve a possibilidade de prevenir a ação, nem de acionar as autoridades públicas competentes, e ainda que, quando o réu praticou o crime buscou meios 
adequados para evitar o mal de terceiros, sendo estes meios na proporção da agressão. Para finalizar as respostas do Júri, entenderam também que o réu não provocou a agressão que circunstanciou a fatalidade. Mesmo o Júri tendo sido novamente estruturado para o novo julgamento, a decisão votada foi praticamente à mesma do primeiro julgamento.

Encerrando a sessão, o Dr. José Cesar de Almeida, em conformidade com a decisão votada pelo Tribunal do Júri, deferiu a absolvição do réu Henrique Wolland, em 10 de março. Segundo a Sentença do referido Juiz, o Alvará de Soltura de Henrique Wolland foi expedido em 15 de março de 1916:

MANDO ao carcereiro da Cadeia Pública desta cidade que, sendo-lhe este apresentado, estando por mim assignado, relaxe da prisão e ponha incontinenti em liberdade, se por AL não se achar preso, o réo Henrique Wolland, visto ter sido o mesmo absolvido pelo Jury em sessão de dez do mez corrente e ter decorrido o prazo da Lei sem que fosse interposto recurso algum. O QUE CUMPRA-SE. (idem; ibidem, p. 97).

Após o desfecho do julgamento de Henrique Wolland, ou mesmo do Alemãozinho, e a respectiva absolvição de parte da Justiça, sabe-se muito pouco ou quase nada a respeito de sua pessoa, que protagonizou o conflito social do Contestado com apenas 21 ou 22 anos de idade, mas que durante sua possível vida posterior a esse contexto, tornou-se obsoleto as páginas da História. Entretanto, é fato que foi julgado em Rio Negro, questão esta até então desconhecida pela Historiografia do Contestado, e que de alguma forma, seja rendendo-se ou mesmo capturado pelas forças do Estado, Alemãozinho não foi sumariamente julgado como subversivo, nem mesmo como transgressor pela Justiça, mas sim respondeu na condição de civil ao crime que cometeu por conta de sua passagem por Rio Negro, em agosto de 1914.

\section{NOTAS:}

${ }^{1}$ Conflito social armado, ocorrido na região centro-oeste e planalto-norte do Estado de Santa Catarina e sul do Paraná, entre os anos de 1912 a 1916, decorrente de caboclos que resistiram à ofensiva das divisões policiais, estando em meio à disputa política, econômica e territorial frente à litigiosa questão de divisas territoriais entre ambos Estados, somada aos interesses dos Coronéis locais, da construtora da Estrada de Ferro (Brazilian Railway Company) e da Madeireira norte-americana Lumber S.A..

${ }^{2}$ Grupo de homens destinados à guarda ou combate armado (cf. Fernando Tokarski). 
${ }^{3}$ Dá-se a designação de Doze Pares da França à tropa de elite pessoal do rei Carlos Magno da França, formada por doze cavaleiros leais ao rei, liderados por Rolando, sobrinho de Carlos Magno. A expressão doze pares se dá pelo fato dos doze cavaleiros terem extrema semelhança entre si, em termos de força, habilidade com armas e lealdade ao rei, e daí o termo par.

${ }^{4}$ Designação popular dada aos caboclos que tomaram parte na Guerra do Contestado (cf. Fernando Tokarski).

5 Matar alguém: $\S 2^{\circ}$ Se o homicídio não tiver sido agravado pelas referidas circunstâncias: Pena de prisão celular por seis a vinte e quatro anos. (cf. Código Penal de 1890).

6 Locução adverbial latina, empregada para exprimir imediatamente, sem demora, sem qualquer perda de tempo. (cf. Dicionário de Expressões Jurídicas).

7 Não serão também criminosos: $\S 2^{\text {o }}$ Os que o praticarem em defesa legitima, própria ou de outrem. A legitima defesa não é limitada unicamente á proteção da vida; Ela compreende todos os direitos que podem ser lesados. (cf. Código Penal de 1890).

8 Exposição escrita e articulada daquilo que se pretende provar contra um réu, concluindo com a declaração da pena, a que, na forma da lei, deve o réu ser condenado. (cf. Dicionário de Expressões Jurídicas).

9 Nascido em Itajaí, Santa Catarina, em 1858, formou-se agrimensor, e desde muito jovem esteve ligado com atividades comerciais portuárias e fluviais no Vale do Itajaí. Em 1892, veio junto de sua família residir em Rio Negro, instalando-se em sua residência construída próxima a margem direita do rio Negro, onde construiu também o porto para os vapores que chegavam de Porto União da Vitória, transportando entre outras mercadorias, os carregamentos de Erva-Mate. Grande empreendedor da navegação fluvial do rio Negro fundou em 1893 a empresa de transporte fluvial e comércio Kirchner \& CIA., juntando-se, em 1915, com o também rio-negrense Coronel Nicolau Mäder, na criação da Lloyd Paranaense (companhia de navegação fluvial) dos rios Iguaçu, Negro e afluentes. Coronel de grande prestígio econômico e social, em 1916 foi eleito Vereador para a Câmara Municipal de Rio Negro, cumprindo o mandato até 1920, quando em 1921 foi eleito Presidente da Câmara e Prefeito Municipal, permanecendo até 1924. Foi ainda Coronel da Guarda Nacional, Diretor do Partido Republicano de Rio Negro e Juiz de Direito Substituto. Faleceu em Rio Negro, em 1927.

10 Nascido em Curitiba, ainda Província de São Paulo, em 1843, filho de Francisco Joaquim Monteiro e Dona Cândida Maria da Silva, iniciou sua vida pública como escrivão de autos da então Freguesia de Rio Negro, em 1862. Participou ativamente do processo de emancipação política de Rio Negro da Vila do Príncipe, em 1870, tornando-se vereador, eleito em 1873. Quando instaurado o Registro Civil do Império do Brasil, em 1876, já reconhecido escrivão de autos e cartorário de notas de Rio Negro, tornou-se também o escrivão dos casamentos, nascimentos e óbitos do mesmo registro, ano este em que se reelegeu como vereador. Em 15 de abril de 1882, fora empossado ao primeiro cargo de Advogado da Câmara de Rio Negro, considerado o melhor preparado para esta função, ainda que não fosse bacharel em Direito, mas sim provisionado. Em 1883, na ocorrência das eleições para novos vereadores, Saturnino Olintho da Silva se elegeu com a maioria dos votos, tornando-se o Presidente da Câmara 
Municipal, destacando-se como advogado de Rio Negro frente aos interesses de Santa Catarina pelas terras paranaenses contestadas. Em 10 de dezembro de 1884, fez parte da comissão que, juntamente com o Coronel Miguel José Grein e demais autoridades, recepcionou a visita do Conde d'Eu em sua passagem pela Vila de Rio Negro. Em 1885, se elegeu novamente vereador, passando a presidência da Câmara para o cidadão João Vieira Ribas. Após o fim da repercussão da Revolução Federalista em Rio Negro (1893-1895), a vida política e social da Vila aos poucos voltou ao normal. Nesse contexto, em janeiro de 1897 foi instalada a Comarca de Rio Negro, sendo o Sr. Saturnino Olintho da Silva nomeado Promotor Público interino. Em 14 de julho de 1899, esteve presente na cerimônia de inauguração do prédio da Câmara Municipal de Rio Negro, ou, do Paço da Câmara Municipal de Rio Negro, durante a administração do Prefeito Municipal Coronel Joaquim Teixeira Sabóia. Entre os anos de 1900 a 1904 e 1904 a 1908, reelegeu-se novamente Vereador. Em meados de 1915, provavelmente aos 72 anos, Saturnino Olintho da Silva assumiu o ofício de acusação do réu Henrique Wolland, como Promotor Público interino, na ausência do Promotor Público titular, o Dr. João Dias de Paiva. Faleceu em Rio Negro, durante o decorrer do Processo Judicial de Henrique Wolland, em 1915.

${ }^{11}$ Juiz de Fato é o cidadão comum que integra o corpo de jurados de um tribunal do Júri. É considerado no âmbito jurídico como Juiz leigo. Compõe o Júri por atender os requisitos exigidos na legislação. 0 termo originado no latim é de facto. (cf. Dicionário de Expressões Jurídicas).

12 Que atenua, ameniza e que diminui a gravidade de um dano, de um crime. Circunstância atenuante, fato que tende a diminuir a gravidade do crime, do delito, e a reduzir à pena. (cf. Dicionário de Expressões Jurídicas).

13 São circunstâncias atenuantes: $\S 3^{\circ}$ Ter o delinquente cometido o crime em defesa da própria pessoa ou de seus direitos, ou em defesa das pessoas e direitos de sua família ou de terceiro; $\S 5$ o Ter precedido provocação ou agressão da parte do ofendido; $§ 6^{0}$ Ter o delinquente cometido o crime para evitar mal maior (cf. Código Penal de 1890).

\section{REFERÊNCIAS}

ALMEIDA, Raul de. História de Rio Negro. Curitiba: IHGPR, 1976.

CELESTINO, Ayrton Gonçalves. Os Bucovinos do Brasil e a História de Rio Negro. Curitiba: Torre de Papel, 2002. 
Código Penal de 1890. Disponível em:

http://legis.senado.gov.br/legislacao/ListaNormas.action?numero=847\&tipo norma=DEC\&d $\underline{\text { ata }=18901011 \& \text { link}=s ~-~ A c e s s a d o ~ e m ~ 12 / 11 / 2014 . ~}$

FORJAZ, Djalma. Centenário da Colonização Alemã em Rio Negro e Mafra (1829-1929).

Curitiba: Empreza Editora Olivero, 1929.

HORCAIO, Ivan. Dicionário Jurídico Compacto. São Paulo: Primeira Impressão, 2008.

JÚNIOR, Waldemiro Bley. Genealogia da Família Bley. Curitiba: IHGPR, 1987.

MACHADO, Paulo Pinheiro. Lideranças do Contestado. São Paulo: UNICAMP, 2004.

Lista de Procuradores-Gerais. Memorial do Ministério Público do Paraná. Disponível em: http://www.memorial.mppr.mp.br/modules/conteudo/conteudo.php?conteudo=86 Acessado em 18/11/2014.

Lista de Desembargadores. Museu do Tribunal de Justiça do Estado do Paraná. Disponível em: http://www.tjpr.jus.br/desembargadores-tjpr-museu - Acessado em 18/11/2014.

PROCESSO CRIME. Juízo de Direito da Comarca de Rio Negro, Estado do Paraná. Apelante: A Justiça Pública. Réu: Henrique Wolland, 1915-1916.

QUEIROZ, Maurício Vinhas de. Messianismo e Conflito Social. São Paulo: Ática, 1981.

SILVA, Oscar Joseph de Plácido e. Vocabulário Jurídico. 18ª edição. Rio de Janeiro: Forense, 2001.

TOKARSKI, Fernando. Dicionário de Regionalismos do Sertão do Contestado.

Florianópolis: Letras Contemporâneas, 2004. 